\title{
The different levels of interferron gamma capacity production on several stages of leprosy
}

\author{
Mohammad Zen Rahfiludin ${ }^{1}$, Martha Irene Kartasurya ${ }^{1}$, Endang Purwaningsih ${ }^{2}$
}

\begin{abstract}
Abstrak
Informasi mengenai aktivitas imunologik, khususnya pada lepra subklinis, masih kurang. Karena itu, tujuan penelitian ini adalah untuk mengetahui prevalensi lepra subklinis dan kapasitas produksi interferon gamma pada beberapa stadium penyakit lepra. Studi observasional dengan pendekatan potong lintang ini dilakukan di Semarang, Jawa Tengah, Indonesia. Duapuluh enam pasien lepra dan 62 orang yang tinggal serumah dengan mereka ikut dalam penelitian ini. Semua sampel darah (88) diambil dari vena dan kapasitas produksi interferon gamma diperiksa dengan metode Elisa. Enampuluh dua sampel darah orang yang tinggal serumah dengan penderita kusta juga diperiksa IgM anti PGL-1 untuk penentuan lepra stadium subklinis, sehingga terdapat tiga kelompok pada penelitian ini, yaitu pasien lepra (LP), lepra stadium subklinis (SL) dan sero negative (SN). Tigapuluh tiga dari 62 orang yang tinggal serumah dengan penderita lepra $(53,2 \%)$ sudah masuk kategori lepra stadium subklinis, sedangkan 29 lainnya sero negative. Terdapat perbedaan bermakna $(P=0,001)$ pada kapasitas produksi interferon gamma di antara ketiga kelompok $(L P, S L$ dan $S N)$. Di antara ketiga kelompok tersebut, kelompok LP yang terendah, sementara kelompok SL yang tertinggi kapasitas produksi interferon gammanya. (Med J Indones 2007; 16:224-7)
\end{abstract}

\begin{abstract}
Informations concerning imunological activity in subclinical leprosy is still lacking. Therefore, the objective of this study was to find out the prevalence of subclinical leprosy and interferon- $\gamma(I F N-\gamma)$ production at several stages of leprosy. This observational study using a cross sectional approach was conducted in Semarang, Central Java, Indonesia. Twenty-six leprosy patients and 62 relatives who lived together with the leprosy patients were included in the study. The venous blood samples were taken from all (88) of the subjects. All of the venous blood samples were measured for IFN- $\gamma$ levels by Elisa method. Sixty two blood samples from the relatives who lived together with the leprosy patients were measured for IgM anti PGL-1 to determine the subclinical stage of leprosy. Thus, there were three groups in this study: leprosy patients $(L P)$, subclinical leprosy $(S L)$ and sero-negative subjects (SN). Thirty three of the 62 relatives $(53.2 \%)$ were in subclinical stage of leprosy, while 29 others were not (sero-negative). There was a significant difference $(P=0.001)$ in $I F N-\gamma$ production capacity among the three groups $(L P, S L$ and $S N)$. Among the three groups, the LP group had the lowest, while SL group had the highest IFN-rproduction capacity. (Med J Indones 2007; 16:224-7)
\end{abstract}

Keywords: subclinical leprosy, IgM anti PGL-1, sero negative

Indonesia has the fourth highest number of leprosy cases in the world after India, Brazil and Myanmar. ${ }^{1}$ Therefore, leprosy still contributes to public health problems in Indonesia. The treatment for leprosy takes a long time and the drop out rate is high. Thus, the prevention of leprosy spreading should be promoted, especially among the relatives who live together with the leprosy patient. To promote the prevention program,

\footnotetext{
1 Department of Community Nutrition, Faculty of Public Health, University of Diponegoro, Semarang, Indonesia

2 Department of Clinical Nutrition, Faculty of Medicine, University of Diponegoro, Semarang, Indonesia.
}

the immunopathology of leprosy, especially in the subclinical leprosy should be studied.

The manifestations of leprosy are so varied as it depends on the infected individual's cell mediated immunity. ${ }^{2}$ Since M.leprae is an obligate intracellular parasite, it is claimed that humoral immune responses are insignificant. In contrast, cellular immune responses, which results in macrophage activation are considered to be essential in limiting the bacterial multiplication and direct killing of the infected cells. ${ }^{3}$

The classical theory of immune response against M.leprae is based on the antigen recognition by helper/inducer $\mathrm{T}$ cells, followed by the clonal proliferation and secretions 
of cytokines, including interferon (IFN)- $\gamma$. Ridley and Jopling showed that the enormous variation in the clinical manifestation of leprosy was the results of a spectrum of immunological reactivity. At one end of the spectrum is paucibacillary (PB) leprosy, where the activity of Th1 cells are more dominant and at the other end is multibacillary (MB) leprosy, where there is no specific immune reactivity. ${ }^{4}$ The objective of this study was to find out the difference in IFN- $\gamma$ production capacity among the groups of clinical, subclinical leprosy patients and sero-negative individuals living with a leprosy patient.

\section{METHODS}

This is an observational study using a cross sectional approach conducted from April 2004 through March 2005. This study was approved by the Medical Ethics Committee of the Faculty of Medicine, University of Diponegoro / Dr. Kariadi Hospital, Semarang, Indonesia. The subjects of this study were leprosy patients that were diagnosed in Tugurejo hospital, Semarang from September $1^{\text {st }}, 2003$ through August $12^{\text {th }}, 2004$, and their relatives who lived together with the patients for at least 3 months. The data were obtained from medical records.

Diagnosis of leprosy was based on the findings of acid fast bacilli. The leprosy patients were divided into MB and PB leprosy: i.e. the patients with 5 lesions or less and diagnosed as intermediate, tuberculoid and borderlinetuberculoid leprosy were regarded as PB, and patients with more than 5 lesions and diagnosed as borderline lepromatous and lepromatous leprosy, were regarded as MB. All patients and their relatives who agreed to participate were included in this study. Exclusion criteria: patients or relatives who refused to give blood samples, or aged less than 17 or more than 60 years old.

Five mls of venous blood was drawn from each subject. The whole blood was centrifuged to separate the serum, which then stored at $-20^{\circ} \mathrm{C}$. Screening for subclinical leprosy for the relatives who stayed together with the leprosy patients was done by IgM anti PGL-1 test. These measurement was conducted in Tropical Disease Center, University of Airlangga, Surabaya. The INF- $\gamma$ capacity production was analysed using ELISA commercial kits (Quantikine ${ }^{\circledR}$, catalog number DIF50, R\&D system, Minneapolis, USA) and was conducted by IDD Lab in Faculty of Medicine, Diponegoro University, Semarang.
The relatives were examined physically by a dermatologist. When they didn't show signs of leprosy and the level of IgM anti PGL-1 was less than 600, they were regarded as sero-negative ( $\mathrm{SN})$, but if the level of IgM anti PGL-1 was more than 600, they were regarded as sero-positive or subclinical leprosy (SL).

Analysis of the data was done using SPSS 10.1 for Windows. The levels of INF- $\gamma$ capacity production among LP, SL and SN group were compared using Kruskall Wallis and Mann Whitney - U test, and $P$-values $<0.05$ were considered as significant different. Further, IFN $-\gamma$ levels of MB and PB patients were compared using Mann Whitney-U test, and boxplots-to compare IFN- $\gamma$ levels in LP, SN and SL group, and between $\mathrm{MB}$ and $\mathrm{PB}$ group-were made.

\section{RESULTS}

Total subjects were 88,26 were leprosy patients and 62 others were relatives who lived together with the leprosy patients. All of the subjects lived in Semarang, Indonesia.

There was no significant difference in age and sex among the three groups (LP, SL and SN). Table 1 shows the characteristics, IFN- $\gamma$ production, and IgM anti PGL-1 levels of the three groups.

Table 1. Subject's characteristics, INF - $\gamma$ production and IgM anti PGL-1 levels

\begin{tabular}{lccc}
\hline \multirow{2}{*}{ Characteristics } & \multicolumn{3}{c}{ Groups } \\
\cline { 2 - 4 } & $\begin{array}{c}\mathrm{LP} \\
(\mathrm{n}=26)\end{array}$ & $\begin{array}{c}\mathrm{SL} \\
(\mathrm{n}=33)\end{array}$ & $\begin{array}{c}\mathrm{SN} \\
(\mathrm{n}=29)\end{array}$ \\
\hline Sex & & & \\
$\quad$ Male $(\%)$ & 84.6 & 27.3 & 44.8 \\
$\quad$ Female $(\%)$ & 15.4 & 72.7 & 55.2 \\
Age $($ years $)$ & $30.1 \pm 11.5$ & $31.2 \pm 11.1$ & $33.1 \pm 10.8$ \\
$($ mean \pm SD) & & & \\
IFN $-\gamma$ production & $483 \pm 691$ & $1522 \pm 1068$ & $977 \pm 547 *$ \\
$(\mathrm{pg} / \mathrm{mL}$, mean \pm SD) & & & \\
IgM anti PGL-1 & $\mathrm{NM}$ & $1121 \pm 475$ & $206 \pm 163$ \\
$(\mathrm{unit} / \mathrm{mL}$, mean \pm SD) & & & \\
\hline
\end{tabular}

* significant difference $(P<0.05)$, with Kruskal Wallis Test $\mathrm{NM}=$ not measured

Figure 1 shows the box plot of the IFN- $\gamma$ capacity production of the three groups, while the $P$-values of the results of Mann Whitney-U test among the groups is shown in Table 2. 
Table 2. $P$-values of the difference between groups*

\begin{tabular}{cccc}
\hline Group & LP & SL & SN \\
\hline LP & - & 0.001 & 0.001 \\
SL & 0.001 & - & 0.046 \\
SN & 0.001 & 0.046 & - \\
\hline
\end{tabular}

* Mann Whitney U tests

There was a significant difference in IFN- $\gamma$ capacity production between $\mathrm{MB}$ and $\mathrm{PB}$ group, and figure 2 shows the difference of the IFN- $\gamma$ capacity production between the two groups.

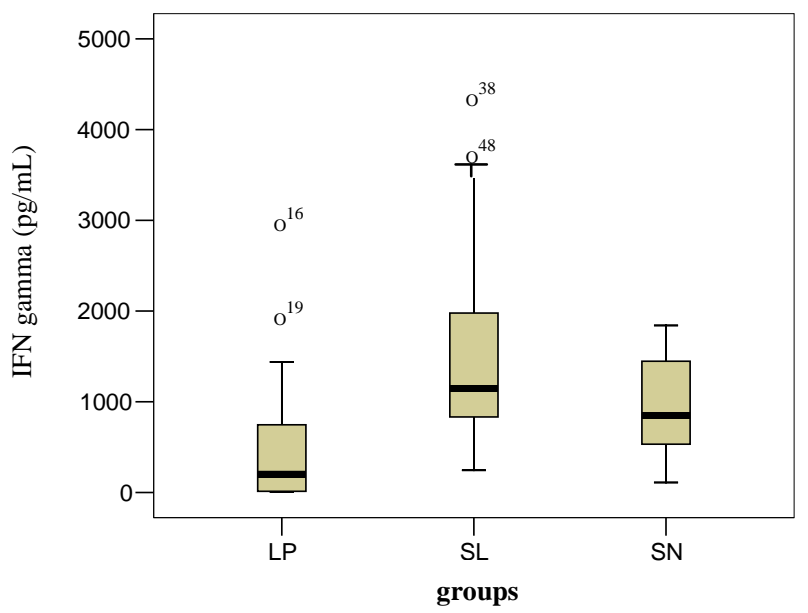

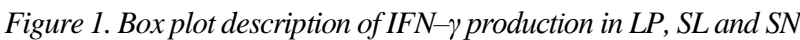

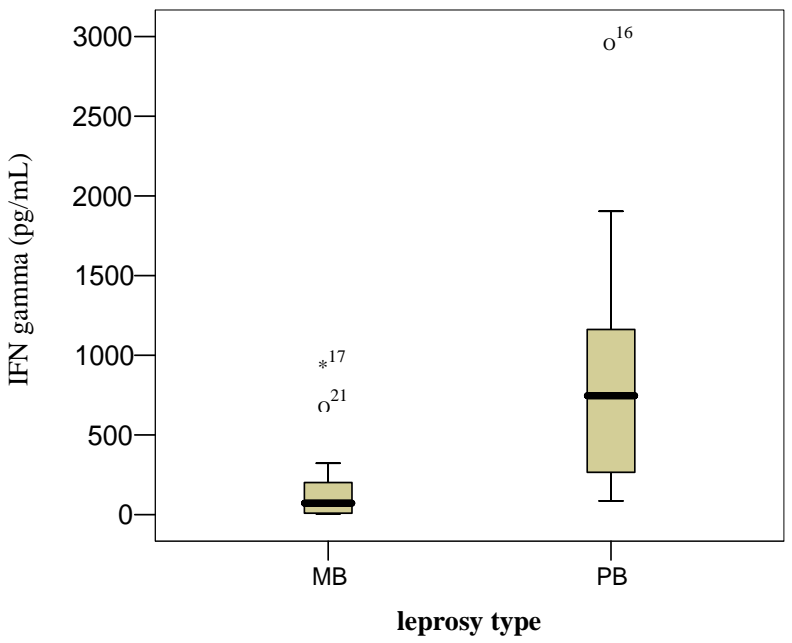

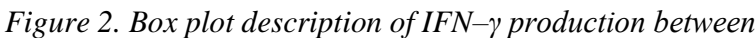
$M B$ and $P B$ leprosy patients

\section{DISCUSSION}

The development of serologic methods for specific antibodies against $M$. Leprae lead to more findings of the sero-positive persons among those who were in close contact with leprosy patients. In the literature, SL (sero-positive leprosy) was identified as subjects, who have specific antibody against M. leprae, without clinical signs of leprosy. ${ }^{5}$

In this study, $53.2 \%$ of the relatives who lived together with leprosy patients were having sero-positive or subclinical leprosy. This result was higher compared to the result of a study in Papua New Guinea, which showed $15 \%$ of SL, ${ }^{6}$ but almost the same as the prevalence in South Sulawesi, which showed the prevalence of $55.6 \%{ }^{7}$

In this study, the IFN- $\gamma$ production capacity of the LP group was the lowest among the three groups. The LP group consisted of 15 subjects who had MB and 11 subjects who had PB leprosy. In MB type of leprosy, IFN- $\gamma$ producing Th1 cells are anergic. On the other hand, the activity of Th2 cells are more apparent. The capacity of IFN- $\gamma$ production in this group was low, and might be due to the anergic Th1.

Furthermore, there is unresponsiveness to IFN- $\gamma$, and the unresponsiveness is most obvious toward the lepromatous pole of the spectrum of leprosy and becomes less severe towards the tuberculoid pole. ${ }^{8}$ Noguiera et al revealed that the $\mathrm{T}$ cells from MB patients failed to produce IL-2 and IFN $-\gamma .{ }^{9}$ The unresponsiveness to IFN- $\gamma$ was evident by the failure of IFN $-\gamma$ to induce enhanced efferent (oxidative burst) and afferent effector function in M. leprae infected macrophage. ${ }^{10}$ At least 4 major mechanisms which are mutually not exclusive are responsible for the unresponsiveness: (1) direct inhibition of $\mathrm{T}$ cells, macrophage or both by M. leprae, (2) inhibition of $\mathrm{T}$ cell responses by soluble factors from $\mathrm{M}$. leprae stimulated macrophage, (3) development of antigen specific suppressor T cells, (4) inhibitory effects by helper and or cytolytic T cells.

In this study, the production capacity of IFN- $\gamma$ in SL group was the highest among the three groups (LP,SL and $\mathrm{SN}$ ), and therefore the difference in activity of Th1 cells in SL stage was the most apparent compared to the LP group. The production capacity of IFN- $\gamma$ in SL stage was also different $(P=0.046)$ from the $\mathrm{SN}$ group. We supposed that the subjects in $\mathrm{SN}$ group just moved into adaptive immunity from innate immunity 
phase. Mean IgM anti PGL-1 in SN group was much lower compared to SL group. The higher level of antibody titre in SL group showed that the number of bacteria in the body was high enough and had been there for a long time. The larger number of bacteria and the longer time of interaction between macrophages and the Th1 cells in the SL stage might result in the higher production of IFN- $\gamma$ compared to the $\mathrm{SN}$ group.

The SL group may develop into clinical stage of leprae or stay in the SL stage, without clinical signs of leprosy. ${ }^{3}$ An other interesting finding was the wide range of IFN- $\gamma$ production levels in SL stage. It is not clear whether the SL subjects with low IFN- $\gamma$ production will develop into the clinical stage of MB leprosy, and the SL subjects with higher IFN- $\gamma$ production will stay in SL stage or develop into PB leprosy. It is possible that the two poles of immunity spectrum in clinical leprae also exist in the SL stage. ${ }^{5}$

In conclusion, the prevalence of SL among the relatives who stayed together with the leprae patients in Semarang was $53.2 \%$. The IFN- $\gamma$ production capacity was different between LP, SL and SN stages.

\section{Acknowledgements}

We are grateful to Prof. Shinzo Izumi, $\mathrm{MD}, \mathrm{PhD}$ and Prof. Indropo Agusni, MD, DV, from the leprosy study group of tropical disease center, Airlangga University, Surabaya for the permission to do IgM anti PGL-1 assay. We also thanked I Gusti Putu Yuliartha, MD, DV for his professional help in recruiting, screening and blood collection process of this study.

\section{REFERENCES}

1. Rosmini DR. Leprosy control programme in Indonesia; achievement and problem. In: Agusni L, editor. Bibliography of Leprosy in Indonesia II. Surabaya: Airlangga University Press; 2003.p.73.

2. Yawalkar SJ. Leprosy for medical practitioners and paramedical workers. $7^{\text {th }}$ ed. Basle: Novartis Foundation for Sustainable Development; 2002.

3. Harboe M. Overview of host - parasite relations. In: Hasting RC, editor. Leprosy. $2^{\text {nd }}$ ed. New York: Churchill Livingstone; 1994.p.87-112.

4. Grange JM. Pathogenesis of mycobacterial disease. In: Gangadharam PRJ, Jenkins PA, editors. Mycobacteria I: Basic aspects. New York: Chapman \& Hall; 1998.p.145-63.

5. Agusni I. Perubahan pola imunopatologik sebagai indikator untuk penanganan kusta stadium subklinik [dissertation]. Surabaya: Airlangga University; 1997.

6. Bagshawe AF, Garcia RF, Baumgart K. IgM serum antibodies to PGL-1 and clinical leprosy: Two years observation in a community with hyperendemic leprosy. Int J Lepr. 1990;58:1.

7. Amiruddin MD, Tabri F, Daud HQ, Abdullah T, Naskur Z. Antibodi anti PGL pada anak-anak kontak serumah di Kabupaten Gowa, Sulawesi Selatan, Indonesia. MDVI. 1994;21:141-3.

8. Kaufmann SHE. Cell-mediated immunity. In: Hasting RC, editor. Leprosy. $2^{\text {nd }}$ ed. New York: Churchill Livingstone; 1994. p.157-68.

9. Nogueira N, Kaplan G, Levy E. Defective $\gamma$ interferon production in leprosy. Journal of Experimental Medicine. 1983;158:2165-70.

10. Krahenbuhl JL. Role of the macrophage in resistance to leprosy. In: Hasting RC, editor. Leprosy, $2^{\text {nd }}$ ed. New York: Churchill Livingstone; 1994.p.137-56 